\title{
In vitro Antacid Screening of the Aqueous and Ethanolic Leaf Extracts of Ixora coccinea (Linn). and Mimosa pudica (Linn.)
}

\author{
SHARMAINE JESSELYN CUA ${ }^{1}$, MARCELINA LIRAZAN ${ }^{2 *}$ and MICHAEL RUSSELLE ALVAREZ ${ }^{3}$ \\ ${ }^{1}$ College of Arts and Science, University of the Philippines Manila, Padre Faura St., Ermita, Manila City, Philippines. \\ ${ }^{2}$ College of Medicine, University of the Philippines Manila, Pedro Gil St., Ermita, Manila City, Philippines. \\ ${ }^{3}$ Institute of Chemistry, University of the Philippines Los Baños, Los Baños, Laguna, Philippines. \\ ${ }^{*}$ Corresponding author E-mail: mblirazan@ up.edu.ph
}

http://dx.doi.org/10.13005/ojc/340504

(Received: July 24, 2018; Accepted: September 28, 2018)

\begin{abstract}
Ixora coccinea L. (santan) and Mimosa pudica L. (makahiya) ethanolic and aqueous extracts were screened for their in vitro antacid potentials using the preliminary antacid test, determination of acid neutralization capacity, acid neutralizing effect, duration of consistent neutralization, and buffering capacity. Phytochemical screening and quantification of alkaloids were also done and the alkaloid content was correlated to the in vitro antacid potentials of the extracts. Among the extracts, the $M$. pudica aqueous extract gave the best preliminary antacid test result $(1.0066 \pm 0.0083 \mathrm{pH})$ and acid neutralization capacity $(0.0711 \pm 0.0038 \mathrm{mmol} \mathrm{H}+)$. Its aqueous extract showed comparable acid neutralizing effect (3.507\% acid neutralized) on gastric juice with that of its ethanol extract (3.509\% acid neutralized). On the other hand, the I. coccinea aqueous extract had the highest acid buffering capacity $(0.0701 \pm 0.0020 \mathrm{mmol} \mathrm{H}+/ \mathrm{pH})$. Both aqueous extracts gave the longest duration of neutralization with $9 \pm 1.732$ minutes. All the extracts were tested positive for flavonoids, indoles, tannins, anthraquinones, anthrones, and alkaloids, with the I. coccinea aqueous extract having the highest alkaloid content (18.0282 $\pm 1.2607 \% \mathrm{w}$ alkaloid/w extract). This study provides the first reported proof of the antacid activities of I. coccinea and M. pudica. Further tests, including mouse model assays, are suggested to determine the efficacy of the extracts in vivo.
\end{abstract}

Keywords: Ixora coccinea, Mimosa pudica, antacid potential.

\section{INTRODUCTION}

Due to the high prevalence of peptic ulcer, there is an increasing demand for a new anti-ulcer drug. In the Philippines alone, 4,135 peptic ulcer cases were reported in $2007^{1}$. Common antacid preparations that are available contain either of these active ingredients: calcium carbonate, sodium bicarbonate, aluminum hydroxide, and magnesium compounds such as magnesium hydroxide ${ }^{2}$. Regular use of these antacid preparations may lead to serious adverse effects such as constipation, diarhea, and even chronic renal failure ${ }^{3}$. Therefore, there is a need for an alternative that will provide the same beneficial effects but with less adverse effects.

This is an Open Access article licensed under a Creative Commons Attribution-Non Commercial-Share Alike 4.0 International License (https://creativecommons.org/licenses/by-nc-sa/4.0/), which permits unrestricted Non Commercial use, distribution and reproduction in any medium, provided the original work is properly cited. 
Due to this, many researchers are now seeking for natural ways of combatting these stomach disorders as well as their symptoms. Previous studies have shown that plants such as Hordeum vulgare $\mathrm{L}$. and Triticum aestivum L. possess in vitro antacid activities $^{4}$. Mimosa pudica L. [Synonyms: Mimosa pudica var. pudica, Mimosa pudica var. tetrandra (Willd.) DC., Mimosa pudica var. unijuga (Duchass. \& Walp.) Griseb.], with common names shameplant, touch-me-not and local name makahiya is a medicinal plant, as well as a vegetable, spice, cosmetic oil, and cooking ingredient ${ }^{5}$. Previous studies have shown that M. pudica L. exhibits various pharmacological activities including wound healing, antimicrobial, antioxidant, analgesic and anti-inflammatory, anticonvulsant, antidiarrheal, antimalarial, anti-hepatotoxic, antihelminthes, antihyperglycemic, antivenom, and anti-ulcer activities 6 . I. coccinea L. [Synonyms: Ixora coccinea var. aureorosea Corner, Ixora coccinea var. bandhuca (Roxb.) Kurz, Ixora coccinea var. decolorans Corner, Ixora coccinea var. hermannii Fosberg \& Sachet, Ixora coccinea var. linneana Kurz, Ixora coccinea var. lutea (Hutch.) Corner, Ixora coccinea var. rosea Corner] with common names jungle germanium, jungle flame and local name santan, on the other hand, is an ornamental shrub. Its leaf extract possesses anti-diarrheal, antimicrobial, antinociceptive, and anti-ulcer activity. Flowers are used to treat dysentery, hemoptysis, and catarrhal bronchitis, and roots were observed to possess stomachic and sedative activities ${ }^{7}$. Preliminary phytochemical screening showed the presence of phytochemicals such as alkaloids, tannins, flavonoids, carbohydrates, proteins, amino acids, glycosides, and reducing sugars.

The present study aims to evaluate the in vitro antacid activities of $I$. coccinea and $M$. pudica ethanolic and aqueous extracts using the preliminary antacid test, determination of acid neutralization capacity, neutralizing effect, duration of consistent neutralization and acid buffering capacity. It also includes phytochemical screening, focusing on the amount of alkaloids in the plant extracts.

\section{MATERIALS AND METHODS}

\section{Materials and Reagents}

Mature leaves of I. coccinea were obtained from Karuhatan, Valenzuela City and fresh leaves of
M. pudica were obtained from Candaba, Pampanga. Voucher samples were submitted to the Botany Division, National Museum of the Philippines for authentication and safekeeping.

Solvents and chemicals used in the study were technical grade (Belman, Philippines; Sigma Aldrich, Singapore). All pH measurements were determined using the Ohaus Starter 300.

\section{Preparation of Artificial Gastric Juice and Stomach Model}

The artificial gastric juice $(2 \mathrm{~g} \mathrm{NaCl}, 3.2$ mg pepsin, $7 \mathrm{~mL} 12 \mathrm{M} \mathrm{HCl}$, diluted to $1 \mathrm{~L}$, $\mathrm{pH}$ 1.2) was prepared according to the simulated gastric fluid test solution by the United States Pharmacopeia $(\mathrm{USP})^{8}$, which mimics the gastric juice produced during the fasted state 9 . It was stored at $4^{\circ} \mathrm{C}$ until further use. The artificial stomach model used for the determination of duration of consistent neutralization was prepared as previously reported ${ }^{10,11}$. It consisted of three elements: peristaltic pump, $\mathrm{pH}$ meter and artificial stomach.

\section{Preparation of Crude Extracts}

Fresh leaves of $I$. coccinea and M. pudica were air dried at room temperature for several days and then ground to fine powder. About $100 \mathrm{~g}$ (dry weight) each was soaked (1:5, w/v) in $95 \%$ ethanol at room temperature for $72 \mathrm{~h}$ or in deionized water at $4^{\circ} \mathrm{C}$ for 24 hours. The samples were extracted five times to ensure complete extraction, then filtered and concentrated in vacuo until all the solvents were removed. Crude extracts were stored in $-41^{\circ} \mathrm{C}$ until further use.

\section{In vitro Antacid Screening: Preparation of Test Solutions}

Stock solutions of the ethanolic and aqueous extracts of $I$. coccinea and $M$. pudica $(100 \mathrm{mg} / \mathrm{mL})$ were initially prepared in absolute ethanol and deionized water, respectively. From the stock solution, a final concentration of $1 \mathrm{mg} / \mathrm{mL}$ was prepared in triplicates. The positive controls used were sodium bicarbonate $(1 \mathrm{mg} / \mathrm{mL}$ in $1 \%$ ethanol or deionized water). The negative controls used were: $1 \%$ ethanol or deionized water. All experimental setups were maintained at $37^{\circ} \mathrm{C}$. The $\mathrm{pH}$ was measured using the Ohaus Starter $300 \mathrm{pH}$ meter. 


\section{Preliminary Antacid Test}

Preliminary antacid test was perfomed as reported previously ${ }^{8}$. Forty milliliters $(40 \mathrm{~mL})$ of each test solution ( $1 \mathrm{mg} / \mathrm{mL}$ sample solution, $1 \mathrm{mg} /$ $\mathrm{mL}$ sodium bicarbonate solution or negative control solution) was continuously stirred for $1 \mathrm{~min}$. to which 10 $\mathrm{mL}$ of standardized $0.5 \mathrm{M} \mathrm{HCl}$ was added. After stirring continuously for $10 \mathrm{~min}$. the $\mathrm{pH}$ was measured.

\section{Determination of the Acid Neutralization Capacity (ANC) Using the Titration Method of Fordtran's Model}

Acid neutralization capacity was determined using the titration method of Fordtran's model ${ }^{12}$. Fifty milliliters $(50 \mathrm{~mL})$ of each test solution $(1 \mathrm{mg} /$ $\mathrm{mL}$ sample solution, $1 \mathrm{mg} / \mathrm{mL}$ sodium bicarbonate solution or negative control solution) was continuously stirred and then titrated with artificial gastric juice until $\mathrm{pH} 3$ was reached. The total acid neutralized $\left(\mathrm{mmol} \mathrm{H} \mathrm{H}^{+}\right.$) was calculated by multiplying the concentration of the artifical gastric juice with the volume of artificial gastric juice added.

\section{Determination of the Neutralizing Effect of Extracts on Artificial Gastric Juice}

Fifty milliliters $(50 \mathrm{~mL})$ of each test solution (1 $\mathrm{mg} / \mathrm{mL}$ sample solution, $1 \mathrm{mg} / \mathrm{mL}$ sodium bicarbonate solution or negative control solution) was added to $55 \mathrm{~mL}$ artificial gastric juice at $\mathrm{pH} 1.2$, and the resulting $\mathrm{pH}$ value was determined.

\section{Determination of the Duration of Consistent Neutralization Using a Modified Artificial Stomach Model}

Fifty milliliters of each test solution (1 mg/ $\mathrm{mL}$ sample solution, $1 \mathrm{mg} / \mathrm{mL}$ sodium bicarbonate solution or negative control solution) was added to $55 \mathrm{~mL}$ of artificial gastric juice at $\mathrm{pH} 1.2$ in the artificial stomach and was continuously stirred at $60 \mathrm{rpm}$. Artificial gastric juice at pH 1.2 was pumped at $3 \mathrm{~mL} / \mathrm{min}$. into the artificial stomach and simultaneously pumped out at $3 \mathrm{~mL} / \mathrm{min}$. The $\mathrm{pH}$ changes were determined in three minute intervals. The duration of neutralization was determined when the $\mathrm{pH}$ value has returned to its initial value $(\mathrm{pH} 1.2)$.

\section{Acid-Buffering Capacity Assay}

Acid-buffering capacity was evaluated based on the Official Methods of Analysis of the Association of Official Analytical Chemists, as reported previously ${ }^{13}$. Forty milliliters $(40 \mathrm{~mL})$ of each test solution ( $1 \mathrm{mg} / \mathrm{mL}$ sample solution, $1 \mathrm{mg} / \mathrm{mL}$ sodium bicarbonate solution or negative control solution) was continuously stirred at 60 rpm. Forward titration was performed by gradual addition of $0.5 \mathrm{~mL}$ standard $\mathrm{HCl}$ solution $(0.099207$ M) until the $\mathrm{pH}$ decreased to 1.5, i.e. physiological stomach $\mathrm{pH}$. The samples were then back titrated by gradual addition of $0.5 \mathrm{~mL}$ standard $\mathrm{NaOH}$ solution $(0.100995 \mathrm{M})$ until the $\mathrm{pH}$ increased to 10 . Initial $\mathrm{pH}$ level and all further measurements taken during titration were recorded after an equilibration period of 1 minute. The acid buffering capacity (BC) was computed based on the equation by Van Slyke (1922): the volume of acid added (from the initial $\mathrm{pH}$ to $\mathrm{pH} 1.5)$ multiplied by the molarity of the acid $(0.099207 \mathrm{M})$, divided by the total change in $\mathrm{pH}^{14}$.

\section{Phytochemical Analysis}

The ethanolic and aqueous extracts of I. coccinea and M. pudica were screened for the presence of flavonoids, alkaloids, tannins, indoles, anthraquinones, and anthrones using standard TLC spray tests ${ }^{15}$.

\section{Determination of Percent Alkaloid Content}

The total alkaloid content was determined gravimetrically using the method of Harbone ${ }^{16}$. Two grams of the extract was weighed and dissolved in $80 \mathrm{~mL}$ of $10 \%$ acetic acid in ethanol. The mixture was shaken and incubated at room temperature for $4 \mathrm{~h}$ before filtering. Then, the filtrate was concentrated to $1 / 4$ of its original volume by evaporation. Concentrated ammonium hydroxide was added dropwise until precipitation was complete. The solution was filtered and the filter paper containing the precipitate was dried in an oven at $60^{\circ} \mathrm{C}$ for $30 \mathrm{~min}$. and then cooled in a dessicator. The final weight was recorded and the total alkaloid content was expressed as a percentage of the sample weight analyzed. The results of the percent alkaloid content were correlated to the results of each in vitro antacid test.

\section{Statistical Analysis}

Data were expressed as mean value \pm SD of three replicate measurements. Statistical analyses were carried out using IBM SPSS Statistics 20. The significance of the differences between controls and test solutions was analyed using analysis of variance (ANOVA) followed by Tukey's multiple comparisons test. Differences at $p<0.05$ were considered to be 
significant $(\alpha=0.05)$. Data analyses were carried out using Microsoft Excel 2013.

\section{RESULTS AND DISCUSSION}

\section{Extraction, Initial pH Values and Preliminary Antacid Test}

After complete extraction of the samples, the percent yields were found to be: M. pudica ethanolic $(20.03 \%)$ and aqueous $(9.17 \%)$ and $I$. coccinea ethanolic (26.12\%) and aqueous (14.47\%).
Table 1 shows that the initial $\mathrm{pH}$ values of the two ethanolic extracts, M. pudica $(\mathrm{pH}=4.63)$ and I. coccinea $(\mathrm{pH}=4.69)$, were not that different. On the other hand, the aqueous $M$. pudica extract has a higher $\mathrm{pH}(\mathrm{pH}=6.17)$ compared to the I. coccinea extract $(\mathrm{pH}=5.46)$. All of the extracts had $\mathrm{pH}$ values that are slightly acidic, with $M$. pudica aqueous having the $\mathrm{pH}$ closest to physiological $\mathrm{pH}$. Moreover, only M. pudica had a $\mathrm{pH}$ value that is less acidic than the negative control.

Table 1: Initial pH values of the negative control, positive control, and plant extracts $(1 \mathrm{mg} / \mathrm{mL})$. Preliminary antacid test results of negative and positive controls, and plant extracts. Result shown is average $\mathrm{pH} \pm \mathrm{SD}$

\begin{tabular}{lcccc}
\hline \multirow{2}{*}{ Sample } & \multicolumn{2}{c}{$\mathrm{pH}$} & \multicolumn{2}{c}{$\begin{array}{c}\text { Preliminary Antacid Test }(\mathrm{pH}) \\
\text { Aqueous }\end{array}$} \\
\hline $\begin{array}{l}\text { Ethanolic } \\
\text { Negative Control* }^{*}\end{array}$ & 5.62 & 5.67 & $0.9879 \pm 0.0023$ & $0.9784 \pm 0.0025$ \\
NaHCO $_{3}$ & & & & \\
$(1 \mathrm{mg} / \mathrm{mL})$ & 8.56 & 8.54 & $1.0389 \pm 0.0008^{\circ}$ & $1.0655 \pm 0.0045^{\circ}$ \\
Mimosa pudica & 4.63 & 6.17 & $0.9909 \pm 0.0022$ & $1.0066 \pm 0.0083^{\circ}$ \\
Ixora coccinea & 4.69 & 5.46 & $0.9879 \pm 0.0033$ & $1.0034 \pm 0.0053^{\circ}$ \\
\hline
\end{tabular}

${ }^{*}$ Negative Control: Ethanolic (1\% Ethanol); Aqueous (Deionized Water) ${ }^{\circ} \mathrm{p}<0.05$ vs negative control. The mean difference is significant at the 0.05 level

The preliminary antacid tests (Table 1) on the plant extracts showed that both ethanolic extracts were not able to increase the $\mathrm{pH}$ significantly compared to the negative control $(p=0.536$ for M. pudica ethanolic; $p=1.00$ for I. coccinea ethanolic, $\alpha=0.05)$. On the other hand, both aqueous extracts showed a significant increase in $\mathrm{pH}(\mathrm{p}<0.0001$ for both extracts, $\alpha=0.05$ ) when compared to the negative control, with the $M$. pudica extract causing a higher change in $\mathrm{pH}$. It can be observed that the results of the modified preliminary antacid test agree with the respective initial $\mathrm{pH}$ values. Furthermore, it can be observed that for all plant samples, the aqueous extracts had consistently higher antacid potential than the ethanolic extracts, although still significantly lower than that of the standard solution of sodium bicarbonate $(\mathrm{p}<0.0001$ for both aqueous extracts, $\alpha=0.05)$.

Table 2: Acid neutralization capacity, acid neutralizing effect on gastric juice and duration of neutralizing effect of the negative and positive controls and plant extracts. Results shown as average $\mathrm{ANC} \pm \mathrm{SD}$

\begin{tabular}{|c|c|c|c|c|c|c|}
\hline \multirow[t]{2}{*}{ Sample } & \multicolumn{2}{|c|}{$\begin{array}{l}\text { Acid Neutralization } \\
\text { Capacity }(\mathrm{mmol} \mathrm{H})\end{array}$} & \multicolumn{2}{|c|}{$\begin{array}{c}\text { Acid Neutralizing } \\
\text { Effect on Gastric Juice } \\
\text { (\%Acid Neutralized) }\end{array}$} & \multicolumn{2}{|c|}{$\begin{array}{c}\text { Duration of } \\
\text { Neutralization (min.) }\end{array}$} \\
\hline & Ethanolic & Aqueous & Ethanolic & Aqueous & Ethanolic & Aqueous \\
\hline$\overline{\text { Negative control* }}$ & $\overline{c--}$ & --- & --- & $\begin{array}{c}-- \\
-1\end{array}$ & --- & --- \\
\hline $\begin{array}{l}\mathrm{NaHCO}_{3} \\
(1 \mathrm{mg} / \mathrm{mL})\end{array}$ & $\begin{array}{c}0.8297 \pm \\
0.0006\end{array}$ & $\begin{array}{c}0.8030 \pm \\
0.0006\end{array}$ & $16.197^{\circ}$ & $13.176^{\circ}$ & $28 \pm 1.732^{\circ}$ & $28 \pm 1.732^{\circ}$ \\
\hline Mimosa pudica & $\begin{array}{c}0.0231 \pm \\
0.0004\end{array}$ & $\begin{array}{c}0.0711 \pm \\
0.0038\end{array}$ & $3.509^{\circ}$ & $3.507^{\circ}$ & $9 \pm 1.732^{\circ}$ & $9 \pm 1.732^{\circ}$ \\
\hline Ixora coccinea & $\begin{array}{c}0.0246 \pm \\
0.0019\end{array}$ & $\begin{array}{c}0.0597 \pm \\
0.0011\end{array}$ & $2.028^{\circ}$ & $2.217^{\circ}$ & $6 \pm 1.732^{\circ}$ & $9 \pm 1.732^{\circ}$ \\
\hline
\end{tabular}

*Negative Control: Ethanolic (1\% Ethanol); Aqueous (Deionized Water) ${ }^{\circ} \mathrm{p}<0.05$ vs negative control. The mean difference is significant at the 0.05 level 
Acid Neutralization Capacity, Acid Neutralizing Effects on Artificial Gastric Juice, Duration of Neutralization

Table 2 shows the acid neutralization capacities, the neutralizing effects of the ethanolic and aqueous extracts on gastric juice, and the duration of consistent gastric acid neutralization. For the ethanolic extracts, Tukey's post hoc test revealed that the acid neutralization capacity (ANC) of I. coccinea ethanolic extract was higher than that of M. pudica, albeit statistically insignificant $(\mathrm{p}=0.694, \alpha=0.05)$. On the other hand, for the aqueous extracts, M. pudica was significantly higher compared to I. coccinea $(p<0.0001, \alpha=0.05)$. Aside from the preliminary antacid test, the acid neutralization capacity (ANC) is often used to evaluate the effectiveness of different antacids. Acid neutralization capacity is the amount of hydrochloric acid an antacid can neutralize, and is expressed as mmol of $\mathrm{H}^{+17}$.

For the acid neutralizing effect on gastric juice (Table 2), Tukey's post hoc test revealed that both ethanolic extracts showed a significant increase in $\mathrm{pH}(\mathrm{p}=0.001$ for $M$. pudica ethanolic; $\mathrm{p}=0.042$ for I. coccinea ethanolic, $\alpha=0.05$ ) when compared to the negative control ( $1 \%$ ethanol). Comparing the two ethanolic extracts, their acid neutralizing effects did not differ significantly $(p=0.171, \alpha=0.05)$. On the other hand, both aqueous extracts showed a significant increase in $\mathrm{pH}$ ( $\mathrm{p}=0.001$ for $M$. pudica aqueous; $p=0.037$ for $l$. coccinea aqueous, $\alpha=0.05$ ) when compared to the negative control (deionized water); the acid neutralizing effects of both aqueous extracts were not statistically significant $(p=0.339$, $\alpha=0.05$ ). The neutralizing effect on artificial gastric juice can be used as a measure of the onset of action of antacids since in this case, the resulting $\mathrm{pH}$ is directly determined upon addition of the sample solution to a fixed volume of the artificial gastric acid. It is an important factor and must be taken into account when evaluating antacid potential since one criterion of an ideal antacid is that it must react rapidly with acids ${ }^{18}$. For both ethanolic and aqueous extracts, the $\mathrm{M}$. pudica extracts have more potent acid neutralizing activities compared to the l. coccinea extracts. These observations are consistent with those observed in the acid neutralization capacities of the aqueous extracts.

The duration of neutralization can also be seen in Table 2. For the ethanolic extracts, M. pudica did not have a significantly longer duration of neutralization compared to $I$. coccinea $(p=0.339, \alpha=0.05)$, while for the aqueous extracts, both of the plants produced the same duration of neutralization. The duration of consistent gastric acid neutralization was evaluated using a modified model of Vatier's artificial stomach which mimics the regular physiological functioning of the human stomach ${ }^{11}$. This model reproduces two major gastric dynamic functions in physiological situations. gastric secretion and gastric emptying. However, only the interaction between the plant extract and the artificial gastric juice simulating the fasted state was monitored, and therefore, interaction with food particles was not included in the study. Moreover, secretion or gastric acid introduction and emptying rates were set at $3 \mathrm{~mL} / \mathrm{min}$. This rate lies within the range for the peak acid output in both males and females.

\section{Acid Buffering Capacity}

Since the aqueous extracts had higher antacid activities than the ethanolic extracts, only the aqueous extracts were screened for their buffering capacities. Table 3 shows the buffering capacities of the aqueous extracts, as well as that of the standard solution of sodium bicarbonate and deionized water. It can be observed that $I$. coccinea aqueous extract has a higher buffering capacity compared to the M. pudica aqueous extract $(p=0.020, \alpha=0.05)$. In contrast to the previous studies on Triticum aestivum and Hordeum vulgare that showed correlation between the acid neutralization capacity, and buffering capacity ${ }^{11}$, I. coccinea exhibited otherwise. Its aqueous extract has higher acid buffering capacity, but with lower acid neutralization capacity and acid neutralizing effect on gastric juice compared to the M. pudica aqueous extract. For the duration of neutralization, the two aqueous extracts, showed the same duration.

Table 3: Acid buffering capacity of positive control and aqueous plant extracts ( $1 \mathrm{mg} / \mathrm{mL}$ ). Acid buffering capacity was determined by dividing the titratable alkalinity $\left(\mathrm{mmol} \mathrm{H}^{+}\right)$by the total change in $\mathrm{pH}$ units

\begin{tabular}{lc}
\hline Sample & $\begin{array}{c}\text { Acid Buffering Capacity } \\
\text { (mmol H+/pH unit) }\end{array}$ \\
\hline Negative control $^{*}$ & --- \\
$\mathrm{NaHCO}_{3}(1 \mathrm{mg} / \mathrm{mL})$ & $0.1060 \pm 0.0082^{\circ}$ \\
Mimosa pudica aqueous & $0.0230 \pm 0.0202$ \\
Ixora coccinea aqueous & $0.0701 \pm 0.0020^{\circ}$ \\
\hline
\end{tabular}

*Negative Control: Ethanolic (1\% Ethanol); Aqueous (Deionized Water) ${ }^{\circ} \mathrm{p}<0.05$ vs negative control. The mean difference is significant at the 0.05 level. 
Phytochemical Screening and Alkaloid Quantification

Phytochemical analysis of the crude ethanolic and aqueous extracts of the plant samples was also performed (Table 4). All extracts tested positive for flavonoids, anthraquinones and anthrones. Moreover, alkaloids, indoles, and tannins were found to be present in all of the crude ethanolic and aqueous extracts. The presence of these phytochemicals could have possibly contributed to the antacid potential of the extracts. Pharmacological properties of alkaloids include analgesic, central nervous stimulant and depressant, antihypertensive, anticholinergic, antitimor, antimalarial activities ${ }^{19}$, as well as anti-ulcer activity ${ }^{20}$. These compounds can react with acid to form crystalline salts without producing water ${ }^{21}$.

Table 4: Phytochemical tests of the crude aqueous and ethanolic extracts

\begin{tabular}{|c|c|c|c|c|}
\hline Phytochemical & $\begin{array}{l}\text { Ethanolic* } \\
\text { M. pudica }\end{array}$ & I. coccinea & $\begin{array}{l}\text { Aqueous* } \\
\text { M. pudica }\end{array}$ & I. coccinea \\
\hline Flavonoids & + & + & + & + \\
\hline Alkaloids & + & + & + & + \\
\hline Indoles & + & + & + & + \\
\hline Tannins & + & + & + & + \\
\hline Anthraquinones & + & + & + & + \\
\hline Anthrones & + & + & + & + \\
\hline
\end{tabular}

*Legend: '+' = positive reaction, '-' = negative reaction

Table 5 shows the total alkaloid content of the ethanolic and aqueous extracts determined gravimetrically using the method of Harborne ${ }^{16}$. For the ethanolic extracts, M. pudica had a higher alkaloid content with $16.5760 \pm 1.3140 \%$ w alkaloid/w extract, compared to $I$. coccinea with $14.7300 \pm 1.3920 \% \mathrm{w}$ alkaloid/w extract. On the other hand, the I. coccinea aqueous extract had a higher alkaloid content with
$18.0282 \pm 1.2607 \% \mathrm{w}$ alkaloid/w extract, compared to the M. pudica aqueous extract which only contains $7.4030 \pm 1.1044 \%$ w alkaloid/w extract. Considering that the M. pudica aqueous extract had the highest acid neutralizing capacity amidst the low alkaloid, it suggests that not only alkaloid content contributes to antacid potentials. There are other compounds that could have contributed to the antacid potentials, such as indoles and tannins.

Table 5: Total alkaloid content of the extracts determined gravimetrically. Results presented in \%w alkaloid/w extract \pm SD

\begin{tabular}{lcc}
\hline & \multicolumn{1}{c}{ Ethanolic } & Aqueous \\
\hline Negative control $^{*}$ & $0.0103 \pm 0.0007$ & \\
Positive control (caffeine) & $103.9228 \pm 1.8186$ & \\
M. pudica & $16.5760 \pm 1.3140$ & $7.4030 \pm 1.1044$ \\
l. coccinea & $14.7300 \pm 1.3920$ & $18.0282 \pm 1.2607$ \\
\hline
\end{tabular}

*Negative Control: Ethanolic (1\% Ethanol); Aqueous (Deionized Water)

\section{CONCLUSION}

Our study provides the first report of the antacid activities of $I$. coccinea and $M$. pudica. Phytochemical analysis showed the presence of alkaloids in all of the extracts. Quantifying the alkaloid content and then correlating the results with the in vitro antacid assay results show a positive correlation with buffering capacity activity and no correlation with the rest. There is, however, consistency in the initial $\mathrm{pH}$, acid neutralization capacity, and acid neutralizing effect of the aqueous extract of M. pudica in being all high, which makes $M$. pudica a better antacid than I. coccinea. However, compared to Triticum aestivum aqueous extract (acid neutralization capacity of $0.0763 \pm 0.0028 \mathrm{mmol} \mathrm{H}^{+}$; acid neutralizing effect of $5.592 \%$ acid neutralized; duration of neutralization of $22 \pm 1.732 \mathrm{~min}$.) in the previous study ${ }^{11}, \mathrm{M}$ pudica aqueous extract (acid neutralization capacity of $0.0711 \pm 0.0038 \mathrm{mmol} \mathrm{H}+$; acid neutralizing effect of $3.507 \%$ acid neutralized; duration of neutralization of $9 \pm 1.732 \mathrm{~min}$.) is second only in terms of antacid 
activity. The authors suggest confirming the bioactivitiy in mouse models, to determine their efficacy in vivo.

\section{ACKNOWLEDGMENT}

The authors would like to thank Dr. Noel
Quiming (Department of Physical Sciences and Mathematics, College of Arts and Sciences, University of the Philippines Manila) and Dr. Marilou Nicolas (Department of Physical Sciences and Mathematics, College of Arts and Sciences, University of the Philippines Manila) for letting us use their facilities and equipment for our experiments.

\section{REFERENCES}

1. Colina N. Available from http://www.amrc.org. hk/sites/default/files/Philippines_1.pdf. 2017.

2. Thompson W.USA: International Foundation for Functional Gastrointestinal Disorders. 2009.

3. Maton P.; Burton M. Drugs., 1999, 57(6), 855-870.

4. Azmi L; Singh MK; Akhtar AK. Int J Pharm Life Sci., 2011, 2(11), 1226-1234.

5. Joseph B; George J; Mohan J. Int J Pharm Sci Drug Res., 2013, 5(2), 41-44.

6. Saravanan P, Boopalan E. Int J Applied Bio., 2011, 2(2), 30-34.

7. Neelima N, Sudhakar M, Patil MB, Lakshmi BVS. J Applied Pharm Sci., 2011, 1(10), 172-175.

8. Zagnoli G. United States Patent US5661137 A. 1997.

9. Li Q, Sidhu H. Patent Application Publication US8900575 B2 2006. 2006.

10. Panda V.; Khambat P. Bull Env. Pharmacol. Life Sci., 2013, 2(7), 38-42.

11. Lirazan M, Cua SJ, Alvarez MR. Oriental J Chem., 2018, 34(1), 93-99.

12. Fordtran J.S.; Morawski S.G.; Richardson C.T.
New Eng. J. Med., 1973, 288(18), 923-928.

13. Al-Dabbas M.M.; Al-Ismail K.;Taleb R.A.; Ibrahim S. Am. J. Agri. Bio. Sci., 2010, 5(2), 154-160.

14. Van Slyke D.D. J. Bio. Chem., 1922, 52, 525-570.

15. Aguinaldo A.M.; Espeso E.I.; Guevara B.Q.; Nonato MG. Philippines: UST Publishing House. 2005.

16. Adeniyi S.A.; Ojiekwe C.L.; Ehiagbonare J.E. Afr. J. Biotech., 2009, 8(1), 110-112.

17. Grinshpan D.D.; Nevar T.N.; Savitskaya T.A.; Boiko A.V.; Kapralov N.V.; Sholomitskaya I.A. Pharm. Chem. J., 2008, 42(7), 400-404.

18. Rubino A.M.; Garizio J.E.; Martin J. J. United States Patents US3272703 A. 1966.

19. Dewick P. USA: John Wiley \& Sons Ltd. 2002.

20. de Sousa Falcao H.; Leite J.A.; Barbosa-Filho J.M.; de Athayde-Filho, de Oliveira P.F.; de Oliveira Chaves M.C.; Moura M.D.; Ferreira A.L.; de Almeida A.B.; Souza-Brito A.R.; de Fatima Formiga Melo Diniz M.; Batista L.M. Molecules., 2008, 13, 3198-3223.

21. Boulware R. European Patent Application., 1989. 